Parasitology

October 2015, Volume 142, Issue 12, Pages 1523-1534

http://dx.doi.org/10.1017/S0031182015000967

http://archimer.ifremer.fr/doc/00277/38871/

(c) Cambridge University Press 2015

\title{
Whole-genome amplification: a useful approach to characterize new genes in unculturable protozoan parasites such as Bonamia exitiosa
}

\author{
Prado-Alvarez Maria ${ }^{1,2}$, Couraleau Yann ${ }^{2}$, Chollet Bruno ${ }^{2}$, Tourbiez Delphine ${ }^{2}$, Arzul Isabelle ${ }^{2, *}$
}

${ }^{1}$ Aquaculture \& Fisheries Development Centre, University College Cork, Cooperage Building, Distillery Fields, North Mall, Cork, Ireland

2 IFREMER, RBE-SG2M-LGPMM, Station de La Tremblade, Avenue de Mus de Loup, F-17390 La Tremblade, France

* Corresponding author : Isabelle Arzul, email address : iarzul@ifremer.fr

\begin{abstract}
:
Bonamia exitiosa is an intracellular parasite (Haplosporidia) that has been associated with mass mortalities in oyster populations in the Southern hemisphere. This parasite was recently detected in the Northern hemisphere including Europe. Some representatives of the Bonamia genus have not been well categorized yet due to the lack of genomic information. In the present work, we have applied WholeGenome Amplification (WGA) technique in order to characterize the actin gene in the unculturable protozoan $B$. exitiosa. This is the first protein coding gene described in this species. Molecular analysis revealed that $B$. exitiosa actin is more similar to Bonamia ostreae actin gene-1. Actin phylogeny placed the Bonamia sp. infected oysters in the same clade where the herein described $B$. exitiosa actin resolved, offering novel information about the classification of the genus. Our results showed that WGA methodology is a promising and valuable technique to be applied to unculturable protozoans whose genomic material is limited.
\end{abstract}

Keywords : Bonamia exitiosa, Bonamia ostreae, actin, Haplosporidia, Whole-Genome Amplification 


\section{Introduction}

The protozoan parasites of the genus Bonamia (Haplosporidia) are intra-haemocytic parasites of several oyster species mainly of the Ostrea genus. In Europe, Bonamia ostreae infects the native flat oyster Ostrea edulis causing mass mortalities in natural beds associated with important economic losses (Meuriot and Grizel, 1984). Other representative of the genus, Bonamia exitiosa, was firstly observed in several areas of the Southern hemisphere. In New Zealand, B. exitiosa was described to infect Ostrea chilensis haemocytes (Hine et al. 2001) and in Australia this parasite was detected in the oyster Ostrea angasi (Corbeil et al. 2006). Bonamia exitiosa has been described as the causative agent of devastated mortality events in these areas (Cranfield et al. 2005; Doonan et al. 1994). This parasite is included in the list of exotic notifiable diseases of the Directive 2006/088/EC and in the Aquatic Animal Health Code (OIE, 2013). However, the notification of B. exitiosa in O. edulis from Spain (Abollo et al. 2008) and its detection in Crassostrea ariakensis from North Carolina (Burreson et al. 2004) support the apparent worldwide distribution of this parasite.

Bonamia exitiosa has been observed infecting Ostrea stentina oysters from Tunisia (Carnegie et al, 2014; Hill et al. 2010) and O. edulis from different European countries including Spain (Abollo et al. 2008, Carrasco et al. 2012), Italy (Narcisi et al. 2010), France (Arzul et al. 2010) and United Kingdom (Lonshaw et al. 2013) questioning its impact on native flat oyster populations.

Some difficulties have been found in classifying some of the representatives of the Bonamia group. In some cases, the species affiliation remains still unresolved and the classification attains to genus level such as Bonamia spp. infecting $O$. chilensis from Chile (Campalans et al. 2000; Lohrmann et al. 2009).

Molecular information based on functional genes might offer very valuable information to clarify the taxonomic classification of the group. However these genes are scarce in protozoans. Recent advances in sequencing methodologies such as Next Generation Sequencing (NGS) have allowed the annotation of an important number of genes of the protozoan Mikrocytos mackini (Burki et al. 2013). The inclusion of these functional genes in phylogenomics analyses clarified the phylogenetic position of this organism among rhizarian. Regarding $B$. ostreae, two actin genes and the HSP90 gene are the unique functional genes described to date and also placed Bonamia representatives among haplosporidians (López-Flores et al. 2007, Prado-Alvarez et al. 2013). Actin genes are highly conserved, broadly distributed and are widely used in phylogenetic studies of protozoans (Burki et al. 2010; Leander and Keeling, 2004; López-Flores et al. 2007). However, the reconstruction of the evolution of haplosporidians has been a complicated task due to the lack of enough genomic information. The difficulty in culturing many of these organisms, such as B. exitiosa, hampers the obtaining of proper genomic material.

Amplification of actin gene was attempted on genomic material from $B$. exitiosa infected oysters and also from purified parasites without success. In the present work 
we applied Whole-Genome Amplification (WGA), a genomic approach especially effective when the amount of DNA is limited. The process consists on the amplification of the entire genome based on primer extension yielding a high quality DNA suitable for genotyping, hybridization, cloning and sequencing. This method allowed us to characterize the actin gene of $B$. exitiosa using for first time pure genomic material extracted from purified parasites. The phylogenetic position of Bonamia sp. infected oysters was also studied using the new actin gene described.

\section{Materials and methods}

\section{Bonamia exitiosa purification}

Heart imprints of O. edulis oysters collected from Corsica (France) in August of 2009 were visualized by light microscopy for Bonamia sp. detection. Following the criteria of Robert et al. (2009), the most infected oysters were selected for parasite purification (Mialhe et al. 1988). Bonamia exitiosa infection was confirmed by histological analysis performed on infected oysters sections. The parasite was also sequenced in oysters found positive by restriction fragment length polymorphism (RFLP) analysis with Hae II and Bgl1 on O. edulis genomic DNA. Parasites were counted on Malassez chamber. A total of $7 \times 10^{6}$ parasites were obtained from 4 heavy infected oysters. Cells were centrifuged and saved frozen on $96 \%$ ethanol.

\section{Gill tissues collection}

Small pieces of gill tissues of $O$. edulis from Turkey, United Kingdom, France, Italy and Spain; O. stentina from Tunisia, O. angasi from Australia and O. chilensis from New Zealand and Chile were analyzed (Table 1) and maintained in $96 \%$ ethanol at $4^{\circ} \mathrm{C}$ for further molecular analysis.

\section{Genomic DNA extraction from gills and Bonamia sp. infection detection}

Genomic DNA was extracted from gill tissue (25 mg) using the QIAamp DNA Mini Kit (Qiagen). DNA from gill tissues were adjusted to $100 \mathrm{ng} / \mu \mathrm{l}$ and used as template to detect Bonamia sp. infection by PCR using BO/BOAS primers according to CochennecLaureau et al. (2000). Posterior RFLP analysis with Hae II and Bgl1 (CochennecLaureau et al. 2003; Hine et al. 2001) were assayed on positive amplicons to confirm $B$. ostreae or B. exitiosa infection.

\section{Amplification of B. exitiosa genomic DNA using Whole-Genome Amplification method}

Genomic DNA was extracted from purified parasites (7 x $10^{6}$ cells) using the QIAamp DNA Mini Kit (Qiagen). DNA was adjusted to $10 \mathrm{ng} / \mu \mathrm{l}$ and was amplified using the Illustra GenomePhi V2 Amplification Kit (GE Healthcare), a method based on isothermal strand displacement. Briefly, DNA (10 ng) and sample buffer containing random hexamers primers were heat-denatured at $95^{\circ} \mathrm{C}$ for 3 min and cooled on ice. A master-mix containing Phi29 DNA polymerase, additional random hexamers, 
nucleotides, salts and buffers were added to the mix and isothermal amplification was performed at $30^{\circ} \mathrm{C}$ for $1.5 \mathrm{~h}$. After amplification, the enzyme was inactivated at $65^{\circ} \mathrm{C}$ for $10 \mathrm{~min}$ and the obtained DNA was cooled on ice and quantified.

Actin gene extension from amplified genomic DNA from B. exitiosa

Degenerate primers for actin amplification in Rhizopods (Longet et al. 2004) were tested in Whole-Genome amplified DNA of B. exitiosa purified cells (Table 2). The reaction was carried out in a volume of $50 \mu \mathrm{l}$ with $2 \mathrm{mM}$ of each dNTP, 2.5 units of Taq polymerase (New England Biolabs) using $300 \mathrm{ng}$ of amplified DNA as template. Thermal cycling was $94^{\circ} \mathrm{C}$ for $5 \mathrm{~min}, 40$ cycles of $94^{\circ} \mathrm{C}$ for $1 \mathrm{~min}$ of denaturing, $55^{\circ} \mathrm{C}$ for $1 \mathrm{~min}$ of annealing and $72^{\circ} \mathrm{C}$ for $2 \mathrm{~min}$ of extension, followed by $10 \mathrm{~min}$ of final extension at $72^{\circ} \mathrm{C}$. Bonamia ostrae DNA from infected oysters and distilled water were used as positive and negative controls, respectively.

Amplification of actin gene from gills of Bonamia sp. infected oysters.

Specific primers (BeActI-F/BeActI-R, Table 2) for B. exitiosa actin amplification were designed in a region with low similarity to $B$. ostreae actin sequences. These primers amplified a product of 220 pairs of bases and were used to detect $B$. exitosa actin on genomic DNA from gills of Bonamia sp. infected oysters (Table 1). PCR reactions were performed in a volume of $25 \mu \mathrm{l}$ containing $2 \mathrm{mM}$ nucleotides, 1.5 units of Taq polymerase (New England Biolabs) and $100 \mathrm{ng}$ of genomic material. Thermal cycling was $94^{\circ} \mathrm{C}$ for $5 \mathrm{~min}, 30$ cycles of $94^{\circ} \mathrm{C}$ for $1 \mathrm{~min}$ of denaturing, $60^{\circ} \mathrm{C}$ for $1 \mathrm{~min}$ of annealing and $72^{\circ} \mathrm{C}$ for 2 min of extension, followed by 10 min of final extension at $72^{\circ} \mathrm{C}$.

\section{Cloning and sequence analysis}

PCR products obtained from the amplification of $B$. exitosa actin in Whole-Genome amplified DNA from B. exitosa (867 pb) and DNA from Bonamia sp. infected oysters (220 pb) were directly cloned and transformed on Top 10F competent bacteria using TOPO TA Clonning kit (Invitrogen). Clones of the expected size were selected and plasmid DNA were sequenced from both ends with TOPO-F and TOPO-R primers (Table 2) using the BigDye terminator Cycle Sequencing Ready Reaction Kit and a 3100 Avant Genetic analyzer ABI Prism sequencer (Applied Biosystem). Raw chromatograms were analysed using Chromas 231 software (Technelysium). Sequence assembly, translation, multiple sequence alignment and searches of homology were performed using ExPaSy tools (http://us.expasy.org/tools), ClustalW2 (http://www.ebi.ac.uk/Tools/clustalw2/index. html) and GenBank databases using Blast algorithm (http://ncbi.nlm.nih.gov/blast/).

Phylogenetic analysis 
Nucleotide and amino acid sequences used to construct phylogenetic trees and pairwise analysis were downloaded from the GenBank database or were obtained from this study (Amino acid sequences: BoAct1-1 (CAL69233.1), BoAct1-2 (CAL69234.1), BoAct114 (CAL69228.1), BoAct2-26 (CAL69235.1), BoAct2-34 (CAL69230.1), BoAct2-45 (CAL69236.1); Nucleotide sequences: B. ostreae actin 1 (AM410919.1), B. ostreae actin 2 (AM410922.1), Haplosporidium nelsoni (AY450412.1), Minchinia tapetis (AY450418.1), Minchinia teredinis (AY450421.1), Haplosporidium costale (AY450407.1), Minchinia teredinis (AY450420.1), Haplosporidium louisiana (AY450409.1), Minchinia chitonis (AY450415.1), Urosporidium crescens (AY450422.1), Allogromia sp. actin 1 (AJ132370.1), Reticulomyxa filosa actin 1 (AJ132374.1), Ammonia sp. actin 1 (AJ132372.1), Allogromia sp. actin 2 (AJ132371.1), Reticulomyxa filosa actin 2 (AJ132375.1) and Ammonia sp. actin 2 (AJ132373.1)). Multiple sequence alignments were performed using Clustal W (Thompson et al. 1997). Distance matrixes and phylogenetic trees were conducted using the Neighbor-Joining method under MEGA5 software (Tamura et al. 2011). Statistical confidence of the inferred phylogenetic relationships was assessed by bootstraps of 1,000 and 10,000 replicates.

\section{Results}

Amplification of genomic DNA from B. exitiosa purified parasites by WGA

An initial DNA extraction procedure on a sample of purified parasites containing $7 \mathrm{x}$ $10^{6}$ cells yielded a genomic DNA sample with a concentration of $0.143 \mu \mathrm{g} / \mu \mathrm{l}$ and $260 / 280$ ratio of 2.14. A subsample of $10 \mathrm{ng}$ of genomic DNA was amplified using the Illustra GenomiPhi V2 Amplification Kit (GE Healthcare) by the method of isothermal strand displacement. After $1.5 \mathrm{~h}$ of incubation, the Whole-genome amplified DNA was more than 5-fold higher concentrated obtaining a final concentration of $0.745 \mu \mathrm{g} / \mu \mathrm{l}$. The obtained genomic DNA had proper quality with an A260/A280 ratio of 1.68 and a size higher than $50 \mathrm{~kb}$ with minimum smearing after verification on an agarose gel (0.6 $\%)$.

\section{Characterization of B. exitiosa actin gene}

Degenerate primers previously designed to amplify actin gene (Longet et al. 2004) were tested in Whole-Genome amplified DNA sample from $B$. exitiosa purified parasites (Table 2). The reaction yielded an amplification product of 867 nucleotides that encoded for a 289 amino acid sequence (Fig. 1). Four clones from one PCR product were forward and reverse sequenced and analyzed. No introns were detected in the sequence. Among the three substitutions found in one of the four clones analysis, one at position 62 corresponded to a non-synonymous change where the consensus codon GAA appeared replaced by GTA coding for Valine instead of Glutamic Acid. Maximum identity value, using Blast tools, reached $89 \%$ of homology with $B$. ostreae actin gene-1. The amplified fragment comprised a fraction of the characteristic actin domain including the corresponding binding sites for ATP (Fig. 1, in grey) and the barbed-end binding proteins gelsolin and profiling motives (Fig. 1, underlined). The new $B$. exitiosa actin gene was named BeAct and deposited on the GenBank database with the accession number KM073107. 
Multiple alignment performed on BeAct amino acid sequence with $B$. ostreae actin sequences (BoAct1 and BoAct2) revealed the position of 211 conserved residues among the 7 actin sequences analyzed (Fig. 2). The sequence was highly conserved up to residue 121. BeAct sequence had 26 distinctive positions (Fig. 2, underlined), 44 identities with BoAct1 and 6 identities with BoAct2 (Fig. 2, in grey). Compared to BoAct1, one deletion and one insertion were found in BeAct at position 1 and 290, respectively. Amino acid residue at position 158 showed identity only with one sequence of BoAct1.

Pairwise distance matrix between $B$. exitiosa and $B$. ostreae actin sequences were conducted using Maximum Composite Likelihood model (Table 3). The analysis involved 8 nucleotide sequences composing a final dataset of 614 positions. Results showed less evolutionary divergence between BeAct and BoAct1 (average distance of 0.153) than between BeAct and BoAct2 (average distance of 0.174). Evolutionary divergence among BeAct and each of BoAct sequences were higher than the distance between BoAct1 and BoAct2 (0.140). Ostrea edulis actin was also included in the analysis showing fewer differences (0.298) with $B$. exitiosa than with $B$. ostreae sequences (0.315 with BoAct1 and 0.325 with BoAct2).

\section{Phylogenetic analyses based on B. exitiosa actin gene}

Neighbor-Joining method was used to infer the phylogenetic relationship of B. exitiosa actin among haplosporidian representatives (Fig. 3). The analysis involved 17 nucleotide sequences considering representatives of the genus Bonamia, Minchinia, Haplosporidium and Urosporidum. Allogromia sp., Reticulomyxa filosa and Ammonia $s p$. were considered as outgroup. After removal of all ambiguous positions the final data set had a total of 427 informative positions. The percentage of replicate trees in which the associated taxa clustered together is shown next to the branches. Bonamia exitiosa actin grouped with $B$. ostreae actin gene-1 with a bootstrap value of $75 \%$. Haplosporidum nelsoni resolved in the same clusters as Bonamia representatives. In sister clades grouped Minchinia and Haplosporidium representatives and Urosporidium crescens.

Molecular and phylogenetic characterization of actin sequences obtained from

Bonamia sp. infected oysters

Primers BeActI-F/BeActI-R (Table 2) were designed on $B$. exitiosa actin sequence to amplify the most divergent region compared to $B$. ostreae actin genes. The specific primers yielded a product of 220 nucleotides in genomic DNA obtained from gill tissues of Bonamia sp. infected oysters. Several oyster species from different locations were analyzed to amplify $B$. exitiosa actin (Table 1). Bonamia exitiosa infection was previously confirmed by studying the RFLP on PCR products obtained using BOBOAS primers and sequencing (Cochennec et al. 2000; Hine et al. 2001). Table 4 summarises the total number of actin sequences obtained after analysis of 40 different clones. A single actin sequence was obtained in O. stentina from Tunisia, O. edulis from Turkey, United Kingdom, France-Atlantic coast and Italy and O. chilensis from Chile after the analysis of 2, 4, 3, 8, 3 and 1 clones, respectively. Two different actin 
sequences were obtained in $O$. chilensis from New Zealand and O. edulis from FranceMediterranean coast in 5 and 6 clones, respectively. Three actin sequences were obtained in three clones of $O$. angasi samples from Australia and four different actin sequences were obtained in the analysis of 5 clones in one $O$. edulis sample from Spain. These sequences were deposited on the GenBank database (Table 4).

Multiple nucleotide alignment analysis including 18 different actin sequences obtained from Bonamia sp. infected oysters revealed $100 \%$ identity between the actin sequence from $B$. exitiosa purified parasites and sequences from $O$. chilensis from New Zealand (clone1), O. angasi from Australia (clone 3), O. edulis from France (Atlantic and Mediterranean coasts, clone 2), United Kingdom, Italy and Turkey, and O. stentina from Tunisia (Fig. 4A). Among the 17 mismatches found in the alignment, 6 were specific to Chilean and Spanish clones. Bonamia exitiosa actin sequence from $O$. chilensis from New Zealand (clone 2) and O. angasi from Australia (clone 2) shared one different nucleotide compared to the other sequences. Remaining discrepancies were found in sequences from O. angasi oysters from Australia (clone 1) and O. edulis from France-Mediterranean coast (clone 1). These residues resulted in 12 non synonymous positions in the deduced amino acid sequences. Among them, 7 were observed in sequences obtained in O. edulis from Spain and O. chilensis from Chile.

The evolutionary relationship between actin sequences from different samples was inferred by the Neighbor-Joining method (Fig. 4B). The tree is drawn to scale according to the evolutionary distance (substitutions per site). The analysis involved 23 nucleotide sequences. The final dataset consisted in 217 positions after removing non informative gaps and missing data. Actin sequences of infected $O$. chilensis from New Zealand, $O$. angasi from Australia and O. edulis from Turkey, Tunisia, France (Atlantic and Mediterranean coasts), United Kingdom and Italy grouped with $B$. exitiosa actin sequence with a bootstrap value of $96 \%$. The four different sequences obtained in infected $O$. edulis from Spain and $O$. chilensis from Chilean sample resolved in different branches close to the group containing $B$. exitiosa actin sequence from purified parasites. Bonamia ostreae actin sequences grouped in two different sister taxa into Bonamia genus clade, being $B$. ostreae actin gene- 1 closer to $B$. exitiosa clade.

The pairwise distance of BeAct, BoAct1 and BoAct2 compared to sequences obtained in infected oysters from different origins is shown in Table 5. No difference was observed among actin sequences obtained in $O$. chilensis from New Zealand (clone 1), $O$. angasi from Australia (clone 3) and O. edulis from Tunisia, Turkey, United Kingdom, Italy and France (Atlantic coast and Mediterranean coast clone 2). Low dissimilarity, up to 0.009, were obtained with actin sequences from infected $O$. chilensis from New Zealand (clone 2), O. angasi from Australia (clones 1 and 2) and O. edulis from France-Mediterranean coast (clone 1). The highest divergence was observed between BeAct and the Spanish and Chilean sequences. Overall divergence of BoAct2 was higher than BoAct1. Actin sequences obtained on infected O. angasi from Australia (clone 2) and those obtained on infected O. edulis from Spain (clones 1 and 4) were the most divergent to BoAct1 and BoAct2, respectively. 


\section{Discussion}

Bonamia exitiosa was firstly detected in the Southern Hemisphere causing important mortalities in cultured oysters (Cranfield et al. 2005; Doonan et al. 1994). This parasite was recently detected in European waters however the magnitude of its effect and the reason of its presence in native oyster $O$. edulis are still unknown. Several difficulties have been found in the classification of some representatives of the genus Bonamia leading in some cases to unresolved categorizations. In this sense, beyond morphological descriptions through histological studies, the genomic characterization has become an indispensable tool to completely catalog these species (Hill et al. 2010). Genomic information offer valuable data that allows homology searching in public databases and also inferring the phylogenetic evolution of a group. However, in some cases, as occurs in unculturable protozoans, the obtaining of genomic material becomes an arduous challenge.

In this study we have amplified six folds the concentration of the initial genomic DNA obtained from $B$. exitiosa purified parasites using WGA by isothermal strand displacement with the GenomiPhi V2 DNA Amplification Kit. Among the methods of WGA described to date, the multiple displacement amplification technique was described to be better in genome coverage (Spits et al. 2006; Nelson 2014). Moreover, the GenomiPhi V2 DNA Amplification Kit had higher success rate and higher concentration of high molecular weight DNA compared to similar methods (Bouzid et al. 2010). WGA has been recently applied in human pathogens obtaining satisfactory results (Carret et al. 2005; McLean et al. 2013; Morrison et al. 2007; Seth-Smith et al. 2013). However, to our knowledge this is the first time that this method was tested in a marine mollusk parasite. Using the amplified genomic material as a template and the degenerate primers previously designed by Longet et al. (2004) we succeeded in the amplification of actin in B. exitiosa. This achievement might be related with the use of purified and uncontaminated cells. Since the amplification is unspecific, high relative concentration of exogenous DNA, such as bacteria or host cells in our case, could favor the generation of undesirable products (Pan et al. 2008).

We obtained a fragment of 867 nucleotides that corresponded to the characteristic actin domain found in actin-related proteins (Schutt et al. 1993; Sheterline et al. 1995). Conserved binding sites were found in the amplified fragment including ATP binding sites and gelsolin and profilin binding sites involved in capping the barbed end of actin polymers and their regulation (Korn et al. 1987; Schafer and Cooper, 1995).

Actin is generally encoded by a multigene family in Eukaryotes (Fairbrother et al. 1998; Fyrberg et al. 1980; Schwartz and Rotblum, 1981). The number of actin genes is highly variable in protozoan and increases in multicellular organisms (Sehring et al. 2007). Multiple paralogous genes were characterized in several haplosporidians including Haplosporidum louisiana, M. chitonis, M. teredinis and M. tapetis (Reece et al. 2004). However, other representatives of the group such as Haplosporidium costale and $H$. nelsoni as well as $U$. crescens have a single actin gene described to date. Regarding Bonamia genus, two actin genes were described in B. ostreae (López-Flores et al. 2007) 
and sequence analysis presented herein might suggest that $B$. exitiosa possesses one actin gene. However further works are required to conclude about the number of actin genes present in B. exitiosa genome.

High variability was found regarding the number of introns in actin genes of Haplosporidia (Reece et al. 2004). Bonamia exitiosa, together with $H$. nelsoni and $U$. crescens, could be included in the group of species with an unique actin gene and not introns. Intronless sequences were described to be orthologous (Reece et al. 2004). It was hypothesized that the increase in the number of introns could explain the emergence of multiple genes in haplosporidians (López-Flores et al. 2007).

Comparison of amino acid sequence showed that $B$. exitiosa actin was more similar to $B$. ostreae actin gene- 1 . Both sequences shared $21 \%$ of the amino acid residues and also the 3'end of the fragment amplified by the degenerate primers. The evolutionary divergence between sequences estimated by pairwise distance revealed that the number of base substitutions per site among sequences was lower between $B$. exitiosa actin and $B$. ostreae actin gene- 1 than between B. exitiosa actin and B. ostreae actin gene-2, confirming results obtained by multiple alignment analysis. The actin sequence of the host, $O$. edulis, was also included in the analysis and confirmed that the sequence that we obtained did not correspond to the host. The divergence between the deduced amino acid sequences of $B$. exitosa actin and $B$. ostreae actin gene- 1 was lower than the divergence observed between $B$. ostreae actin genes (López-Flores et al. 2007). Divergence between species and within species can be similar at protein level, as was previously described in Dinoflagellates (Kim et al. 2011). The percentage of amino acid divergence between actin isoforms in protozoans was described to be very variable reaching 16-18 \% in foraminiferans and $40 \%$ in the ciliate Paramecium tetraurelia (López-Flores et al. 2007; Keeling 2001, Sehring et al. 2007; Wesseling et al. 1988).

Bonamia genus was described to belong to haplosporidian group among Cercozoa (Carnegie et al. 2000; Cavalier-Smith 2002; Cavalier-Smith and Chao, 2003; Cochennec-Laureau et al. 2000; Prado-Alvarez et al. 2013). The phylogenetic relationship among haplosporidians has been previously ascertained using ribosomal DNA and actin genes (Carnegie et al. 2000; Carnegie et al. 2006; Carrasco et al. 2012; López-Flores et al. 2007; Reece et al. 2004). Regarding Bonamia representatives, phylogenetic analysis based on ribosomal DNA placed B. exitiosa and B. roughleyi $(B$. roughleyi nomen dubitum, Carnegie et al. 2014) in a sister group to $B$. ostreae and $B$. perspora (Abollo et al. 2008; Carnegie et al. 2006; Cochennec-Laureau et al. 2003). The topology of our phylogenetic tree based on actin sequences including the novel $B$. exitiosa actin was in concordance with these previous analyses. Bonamia exitiosa grouped within the clade of Bonamia genus closer to $B$. ostreae actin gene- 1 and in a sister branch to $B$. ostreae actin gene-2 suggesting that $B$. exitiosa have evolved after the differentiation of $B$. ostreae actin paralogs.

The actin sequence obtained in purified $B$. exitiosa parasites perfectly aligned with the currently considered B. exitiosa infected samples from New Zealand, Australia, United Kingdom, Italy, France-Mediterranean coast and Tunisia (Arzul et al. 2011; Corbeil et 
al. 2006; Hine et al. 2001). Sequences obtained in Bonamia sp. infected oysters from France-Atlantic coast and Turkey were also included in the same group, concluding that these uncategorized parasites might be indeed considered B. exitiosa.

The phylogenetic study based on actin sequences supported the inclusion of all the samples in a sister clade to $B$. ostreae sequences with a strong bootstrap support. Molecular analysis comparisons based on nucleotide alignment and pairwise distances among actin sequences revealed that samples from $O$. chilensis from Chile and $O$. edulis from Spain were the most divergent compared to $B$. exitiosa actin sequence. These samples shared 6 of the 17 missmatches found in the multiple alignment and resolved in separated branches within the strongly supported cluster where actin sequence from $B$. exitiosa purified parasites was included. Previous phylogenetic studies based on SSU rDNA placed the Chilean and the Spanish samples in the same group as B. exitiosa (Carrasco et al. 2012; Hill et al. 2010). However, the analysis of ITS1-5,8-ITS2 sequences placed the Chilean clone in a separate branch inside the group of Bonamia sp. representatives (Hill et al. 2010). Our phylogenetic analyses based on the actin gene supported this topology, suggesting a closer relationship between Chilean and Spanish samples. Based on our analysis, we do not have enough support to conclude that Chilean samples were infected with $B$. exitiosa. Therefore, the affiliation of this sample remains uncertain and further investigation would be necessary to clarify its position among Bonamia representatives.

Next-Generation Sequencing (NGS) methods have recently been applied to the protozoan $M$. mackini obtaining novel information that clarified the phylogenetic position of this organism (Burki et al. 2013). However, the impossibility to obtain proper genomic material could limit the use and potential of the NGS in some organisms such as unculturable protozoans. In this sense, the WGA method allows the obtaining of reliable NGS results from limited starting material, reducing also the percentage of undesirable products and enhancing the efficiency of the technique. Some technologies combining both methods have been applied to Eukaryotes and Prokaryotes (Korfhage et al. 2013; Pamp et al. 2012; Young et al. 2012). Data presented in this work demonstrated the successful use of the WGA technique in the unculturable protozoa $B$. exitiosa which might facilitate the application of new promising methodologies in these organisms.

Using Whole-genome amplified genomic DNA we characterized for first time the actin gene on B. exitiosa, increasing the genomic data available in this specie. These new data allow us examining the phylogenetic affiliation of Bonamia sp. representatives and clarified their uncertain classification. To our knowledge this is the first time that WGA methodology is applied in a haplosporidian. This technique might also allow the developing of necessary and specific diagnostic tools to discriminate between $B$. ostreae and B. exitiosa parasites.

\section{Acknowledgements}


The Région of Poitou Charentes and IFREMER supported this research.

\section{References}

Abollo, E., Ramilo, A., Casas, S. M., Comesaña, P., Cao, A., Carballal, M. J. and Villalba, A. (2008). First detection of the protozoan parasite Bonamia exitiosa (Haplosporidia) infecting flat oyster Ostrea edulis grown in European waters. Aquaculture 274, 201-207.

Arzul, I., Omnes, E., Robert, M., Chollet, B., Joly, J. P., Miossec, L., Franand, C. and Garcia C. (2010). Distribution of Bonamia exitiosa in flat oyster Ostrea edulis populations in France. Aquaculture 2010, San Diego, California.

Arzul, I., Aranguren, R., Arcangeli, G., Chesslet, D., Engelsma, M., Figueras, A., Garcia, C., Geoghegan, F., Magnabosco, C. and Stone D. (2011). Distribution of Bonamia exitiosa in flat oyster Ostrea edulis populations in Europe. 15th EAFP International Conferences on Diseases of Fish and Shellfish, Split, Croatia.

Bouzid, M., Heavens, D., Elwin, K., Chalmers, R. M., Hadfield, S. J., Hunter, P. R. and Tyler, K. M. (2010). Whole genome amplification (WGA) for archiving and genotyping of clinical isolates of Cryptosporidium species. Parasitology 137, 27-36.

Burki, F., Kudryavtsev, A., Matz, M. V., Aglyamova, G. V., Bulman, S., Fiers, M., Keeling, P. J. and Pawlowski J. (2010). Evolution of Rhizaria: new insights from phylogenomic analysis of uncultivated protists. BMC Evolutionary Biology 10, 377.

Burki, F., Corradi, N., Sierra, R., Pawlowski, J., Meyer, G. R., Abbott, C. L., and Keeling, P. J. (2013). Phylogenomics of the 'amitochondriate' intracellular parasite Mikrocytos mackini reveals first evidence for a mitosome in Rhizaria. Current Biology 23, 1541-1547.

Burreson, E.M., Stokes, N.A., Carnegie, R.B., and Bishop, M.J. (2004). Bonamia sp. (Haplosporidia) found in nonnative oysters Crassostrea ariakensis in Bogue Sound, North Carolina. Journal of Aquatic Animal Health 16, 1-9.

Campalans, M., Rojas, P. and Gonzalez, M. (2000). Haemocytic parasitosis in the farmed oyster Tiostrea chilensis. Bulletin European Association of Fish Pathologists 20, 31-33.

Carnegie, R. B., Barber, B. J., Culloty, S. C., Figueras, A. J. and Distel, D. L. (2000). Development of a PCR assay for detection of the oyster pathogen Bonamia ostreae and support for its inclusion in the Haplosporidia. Diseases of Aquatic Organisms 42, 199-206.

Carnegie, R. B., Burreson, E. M., Hine, P. M., Stokes, N. A., Audemard, C., Bishop, M. J. and Peterson, C. H. (2006). Bonamia perspora n. sp. (Haplosporidia), a parasite of the oyster Ostreola equestris, is the first Bonamia species known to produce spores. Journal of Eukaryotic Microbiology 53, 232-245. 
Carnegie, R. B., Hill, K. M., Stokes, N. A. and Burreson, E. M. (2014). The haplosporidian Bonamia exitiosa is present in Australia, but the identity of the parasite described as Bonamia (formerly Mikrocytos) roughleyi is uncertain. Journal of Invertebrate Pathology 115, 33-40.

Carrasco, N., Villalba, A., Andree, K. B., Engelsma, M. Y., Lacuesta, B., Ramilo, A., Gairín, I. and Furones, M. D. (2012). Bonamia exitiosa (Haplosporidia) observed infecting the European flat oyster Ostrea edulis cultured on the Spanish Mediterranean coast. Journal of Invertebrate Pathology 110, 307-313.

Carret, C. K., Horrocks, P., Konfortov, B., Winzeler, E., Qureshi, M., Newbold, C. and Ivens, A. (2005). Microarray-based comparative genomic analyses of the human malaria parasite Plasmodium falciparum using Affymetrix arrays. Molecular and Biochemical Parasitology 144, 177-186.

Cavalier-Smith, T. (2002). The phagotrophic origin of eukaryotes and phylogenetic classification of Protozoa. International Journal of Systematic and Evolutionary Microbiology 52, 297-354.

Cavalier-Smith, T. and Chao, E. E. (2003). Phylogeny and classification of phylum Cercozoa (Protozoa). Protist 154, 341-358.

Cochennec-Laureau, N., Le Roux, F., Berthe, F. and Gerard, A. (2000). Detection of Bonamia ostreae based on small subunit ribosomal probe. Journal of Invertebrate Pathology 76, 26-32.

Cochennec-Laureau, N., Reece, K. S., Berthe, F. C. J. and Hine, P. M. (2003). Mikrocytos roughleyi taxonomic affiliation leads to the genus Bonamia (Haplosporidia). Diseases of Aquatic Organisms 54, 209-217.

Corbeil, S., Arzul, I., Robert, M., Berthe, F. C. J., Besnard-Cochennec, N. and Crane, M. S. J. (2006). Molecular characterization of an Australian isolate of Bonamia exitiosa. Diseases of Aquatic Organisms 71, 81-85.

Cranfield, H. J., Dunn, A., Doonan, I. J. and Michael, K. P. (2005). Bonamia exitiosa epizootic in Ostrea chilensis from Foveaux Strait, southern New Zealand between 1986 and 1992. ICES Journal of Marine Science 62, 3-13.

Doonan, I. J., Cranfield, H. J. and Jones, J. B. (1994). Catastrophic reduction of the oyster, Tiostrea chilensis (Bivalvia: Ostreidae), in Foveaux Strait, New Zealand, due to infestation by the protistan Bonamia sp. New Zealand Journal of Marine and Freshwater Research 28, 335-344.

Fairbrother, K. S., Hopwood, A. J., Lockley, A. K. and Bardsley, R. G. (1998). The actin multigene family and livestock speciation using the polymerase chain reaction. Animal Biotechnology 9, 89-100.

Fyberg, E. A., Kindle, K. L., Davidson, N. and Kindle, K. L. (1980). The actin genes of Drosophila: a dispersed multigene family. Cell 19, 365-378.

Hill, K. M., Carnegie, R. B., Aloui-Bejaoui, N., El Gharsalli, R., White, D. M., Stokes, N. A. and Burreson, E. M. (2010). Observation of a Bonamia sp. infecting the 
oyster Ostrea stentina in Tunisia, and a consideration of its phylogenetic affinities. Journal of Invertebrate Pathology 103, 179-185.

Hine, P. M., Cochennec-Laureau, N. and Berthe, F. C. J. (2001) Bonamia exitiosus n. sp. (Haplosporidia) infecting flat oysters Ostrea chilensis (Philippi) in New Zealand. Diseases of Aquatic Organisms 47, 63-72.

Keeling, P. J. (2001). Foraminifera and Cercozoa are related in actin phylogeny: Two orphans find a home?. Molecular Biology and Evolution 18, 1551-1557.

Kim, S., Bachvaroff, T. R., Hand, S. M. and Delwiche, C. F. (2011). Dynamics of actin evolution in Dinoflagellates. Molecular Biology and Evolution 28, 1469-1480.

Korfhage, C., Fisch, E., Fricke, E., Baedker, S. and Loeffert, D. (2013). Wholegenome amplification of single-cell genomes for next-generation sequencing. Current Protocols in Molecular Biology. DOI: 10.1002/0471142727.mb0714s104.

Korn, E. D., Carlier, M. F. and Pantaloni, D. (1987). Actin polymerization and ATP hydrolysis. Science 238, 638-644.

Leander, B. S. and Keeling, P. J. (2004). Early evolutionary history of Dinoflagellates and Apicomplexans (Alveolata) as inferred from HSP90 and actin phylogenies. Journal of Phycology 40, 341-350.

Lohrmann, K. B., Hine, P. M. and Campalans, M. (2009). Ultrastructure of Bonamia sp. in Ostrea chilensis in Chile. Diseases of Aquatic Organisms 85, 199-208.

Longet, D., Burki, F., Flakowski, J., Berney, C., Polet, S., Fahrni, J. and Pawlowski, J. (2004). Multigene evidence for close evolutionary relations between Gromia and Foraminifera. Acta Protozoologica 43, 303-311.

Lonshaw, M., Stone, D. M., Wood, G., Green, M. J. and White, P. (2013). Detection of Bonamia exitiosa (Haplosporidia) in European flat oysters Ostrea edulis cultivated in mainland Britain. Diseases of Aquatic Organisms 106, 173-179.

López-Flores, I., Suárez-Santiago, V. N., Longet, D., Saulnier, D., Chollet, B. and Arzul, I. (2007). Characterization of actin genes in Bonamia ostreae and their application to phylogeny of the Haplosporidia. Parasitology 134, 1941-1948.

McLean, J. S., Lombardo, M. J., Ziegler, M. G., Novotny, M., Yee-Greenbaum, J., Badger, J. H., Tesler, G., Nurk, S., Lesin, V., Brami, D., Hall, A. P., Edlund, A., Allen, L. Z., Durkin, S., Reed, S., Torriani, F., Nealson, K. H., Pevzner, P. A., Friedman, R., Venter, J. C. and Lasken, R. S. (2013). Genome of the pathogen Porphyromonas gingivalis recovered from a biofilm in a hospital sink using a highthroughput single-cell genomics platform. Genome Resarch 23, 867-877.

Meuriot, E. and Grizel, H. (1984). Note sur l'impact économique des maladies de l'huître plate en Bretagne. Rapports Techniques de l'Institut Scientifique et Technique des Péches Maritimes 12, 1-20. 
Mialhe, E., Bachère, E., Chagot, D. and Grizel, H. (1988). Isolation and purification of the protozoan Bonamia ostreae (Pichot et al, 1980), a parasite affecting the flat oyster Ostrea edulis L. Aquaculture 71, 293-299.

Morrison, L. J., Mccormack, G., Sweeney, L., Likeufack, A. C. L., Truc, P., Turner, C. M., Tait, A. and Macleod, A. (2007). Use of multiple displacement amplification to increase the detection and genotyping of trypanosoma species samples immobilized on FTA filters. The American Journal of Tropical Medicine and Hygiene 76, 1132-1137.

Narcisi, V., Arzul, I., Cargini, D., Mosca, F., Calzetta, A., Traversa, D., Robert, M., Joly, J. P., Chollet, B., Renault, T. and Tiscar, P. G. (2010). Detection of Bonamia ostreae and B. exitiosa (Haplosporidia) in Ostrea edulis from the Adriatic Sea (Italy). Diseases of Aquatic Organisms 89, 79-85.

Nelson, J. R. (2014). Random-primed, Phi29 DNA polymerase-based whole genome amplification. Current Protocols in Molecular Biology. DOI: 10.1002/0471142727.mb1513s105.

OIE. (2013). Aquatic Animal Health Code. http://www.oie.int/en/internationalstandard-setting/aquatic-code/access-online/

Pamp, S. J., Harrington, E. D., Quake, S. R., Relman, D. A. and Blainey, P. C. (2012). Single-cell sequencing provides clues about the host interactions of segmented filamentous bacteria (SFB). Genome Resarch 22, 1107-1119.

Pan, X., Urban, A. E., Palejev, D., Schulz, V., Grubert, F., Hu, Y., Snyder, M. and Weissman, S. M. (2008). A procedure for highly specific, sensitive, and unbiased whole-genome amplification. Proceedings of the National Academy of Sciences 105, 15499-15504.

Prado-Alvarez, M., Chollet, B., Couraleau, Y., Morga, B. and Arzul, I. (2013). Heat shock protein 90 of Bonamia ostreae: Characterization and possible correlation with infection of the flat oyster, Ostrea edulis. Journal of Eukaryotic Microbiology 60, 257266.

Reece, K. S., Siddall, M. E., Stokes, N. A. and Burreson, E. M. (2004). Molecular phylogeny of the haplosporidia based on two independent gene sequences. Journal of Parasitology 90, 1111-1122.

Robert, M., Garcia, C., Chollet, B., López-Flores, I., Ferrand, S. F. C., Joly, J. P. and Arzul, I. (2009). Molecular detection and quantification of the protozoan Bonamia ostreae in the flat oyster, Ostrea edulis. Molecular and Cellular Probes 23, 264-271.

Schafer, D. A., Cooper, J. A. (1995). Control of actin assembly at filament ends. Annual Review of Cell and Developmental Biology 11, 497-518.

Schutt, C. E., Myslik, J. C., Rozycki, M. D., Goonesekere, N. C. W. and Lindberg, U. (1993). The structure of crystalline profilin- $\beta$-actin. Nature 365, 810-816. 
Schwartz, R. J. and Rotblum, K. N. (1981). Gene switching in myogenesis: differential expression of the chicken actin multigene family. Biochemistry 20, 41224129.

Sehring, I. M., Mansfeld, J., Reiner, C., Wagner, E., Plattner, H. and Kissmehl, R. (2007). The actin multigene family of Paramecium tetraurelia. BMC Genomics. DOI: 10.1186/1471-2164-8-82.

Seth-Smith, H. M., Harris, S. R., Skilton, R. J., Radebe, F. M., Golparian, D., Shipitsyna, E., Duy, P. T., Scott, P., Cutcliffe, L. T., O'Neill, C., Parmar, S., Pitt, R., Baker, S., Ison, C. A., Marsh, P., Jalal, H., Lewis, D. A., Unemo, M., Clarke, I. N., Parkhill, J. and Thomson, N. R. (2013). Whole-genome sequences of Chlamydia trachomatis directly from clinical samples without culture. Genome Resarch 23, 855866.

Sheterline, P., Clayton, J. and Sparrow, J. C. (1995). Actin. In Protein profile (ed. Sheterline, P.) Vol. 2, Issue 1. Academic Press, New York.

Spits, C., Le Caignec, C., De Rycke, M., Van Haute, L., Van Steirteghem, A., Liebaers, I. and Sermon, K. (2006). Whole-genome multiple displacement amplification from single cells. Nature Protcols 1, 1965-1970.

Tamura, K., Peterson, D., Peterson, N., Stecher, G., Nei, M. and Kumar, S. (2011). MEGA5: Molecular evolutionary genetics analysis using máximum likelihood, evolutionary distance, and maximum parsimony methods. Molecular Biology and Evolution 28, 2731-2739.

Thompson, J. D., Gibson, T. J., Plewniak, F., Jeanmougin, F. and Higgins, D. G. (1997). The Clustal X windows interface: flexible strategies for multiple sequence alignment aided by quality tools. Nucleic Acids Research 25, 4876-4882.

Wesseling, J. G., Smits, M. A. and Schoenmakers, J. G. G. (1988). Extremely diverged actin proteins in Plasmodium falciparum. Molecular and Biochemical Parasitology 30, 143-154.

Young, N. D., Jex, A. R., Li, B., Liu, S., Yand, L., Xiong, X., Li, Y., Cantacessi, C., Hall, R. S., Xu, X., Chen, F., Wu, X., Zerlotini, A. et al. (2012). Whole-genome sequence of Schistosoma haematobium. Nature Genetics 44, 221-225. 


\section{Figure legend}

Figure 1: Nucleotide sequence and deduced amino acid sequence of BeAct. Identical bases found in the alignment of the 4 clones are indicated with dots. Residues involved in ATP binding are indicated in grey. Residues involved in gelsolin and profiling recognition are underlined.

Figure 2: Multiple alignment of actin amino acid sequence of $B$. exitiosa with the two actin genes of $B$. ostreae. Distinctive residues found in BeAct are underlined and the coincidences with each of $B$. ostreae actin genes are marked in grey. Squared amino acid show the location of the specific primers (BeActI-F and BeActI-R) and dot lines show the length of the amplified fragment. .

Figure 3: Neighbor-Joining tree of the nucleotide sequences showing the phylogenetic relationships among actin sequences from haplosporidian representatives. Bootstrap of 10,000 repetitions.

Figure 4: (A) Multiple alignment of actin nucleotide sequence obtained in Bonamia sp. infected oysters including $B$. extiosa actin sequence obtained from purified parasites. Distinctive residues compared to the consensus sequence are marked in grey and non synonymous changes with arrows. (B) Phylogenetic tree between nucleotide actin sequences obtained in Bonamia sp. infected oysters and B. ostreae actin genes and other haplosporidian representatives inferred by Neighbor-Joining. Bootstrap of 1,000 repetitions. 
Table 1: Table showing the origin of the oyster samples analyzed

\begin{tabular}{llll} 
Country & Location (Year of collection) & Specie & Provided by / reference \\
\hline Turkey & Ayvalik (2009) & Ostrea edulis & Boronova Veterinary Control and Research Institute \\
United Kingdom & Cornwall (2011) & Ostrea edulis & English National Reference Laboratory \\
France & Thau (2008) & Ostrea edulis & French Research Institute for Exploitation of the sea \\
& Quiberon (2010) & Ostrea edulis & French Research Institute for Exploitation of the sea \\
& Bouin (2010) & Ostrea edulis & French Research Institute for Exploitation of the sea \\
& Corse (2009) & Ostrea edulis & French Research Institute for Exploitation of the sea \\
Italy & Pellestrina Island,Venize (2011) & Ostrea edulis & Italian National Reference Laboratory \\
Spain & Galicia, Ria de Arousa (2007) & Ostrea edulis & Spanish National Reference Laboratory \\
Tunisia & Monastir Bay (2009) & Ostrea stentina & Institut National Agronomique de Tunisie \\
Australia & Merimbula estuary, NSW & Ostrea angasi & The Commonwealth Scientific and Industrial Research \\
New Zealand & Southern Island (2009) & Ostrea chilensis & Investigation and Diagnostic Centre Biosecurity New Zealand \\
Chile & Chiloe Islands (2010) & Ostrea chilensis & Escuela de Ciencias del Mar, Catolic University Valparaiso \\
\hline
\end{tabular}


Table 2: List of primers used in the study.

Primer

BO (Cochennec-Laureau et al. 2000)

BOAS (Cochennec-Laureau et al. 2000)

Act-degF (Longet et al. 2004)

Act-degR (Longet et al. 2004)

BeActI-F

BeActI-R

TOPO-F

TOPO-R
Sequence (5' - 3')

CATTTAATTGGTCGGGCCGC

CTGATCGTCTTCGATCCCCC

AACTGGAYGAYATGGA

GGWCCDGATTCATCRTAYTC

TCCGGGACATCAAAGAAAAC

ATCGAGTCGTACGCGAGTCT

GACCATGATTACGCCAAGC

CCCAGTCACGACGTTG 
Table 3: Pairwise distance between $B$. exitiosa, B. ostreae and $O$. edulis actin sequences (Maximum Composite Likelihood model).

BoAct1-1 BoAct1-2 BoAct1-14 BoAct2-28 BoAct2-34 BoAct2-45 OeAct

\begin{tabular}{lllllll}
\hline BoAct1-1 & & & & & & 0.317 \\
BoAct1-2 & 0.005 & & & & 0.315 \\
BoAct1-14 & 0.006 & 0.001 & & & & 0.315 \\
BoAct2-28 & 0.141 & 0.142 & 0.142 & & & 0.327 \\
BoAct2-34 & 0.139 & 0.141 & 0.141 & 0.001 & & 0.325 \\
BoAct2-45 & 0.139 & 0.141 & 0.141 & 0.001 & 0.000 & 0.325 \\
BeAct & 0.154 & 0.152 & 0.152 & 0.175 & 0.173 & 0.173 \\
\cline { 2 - 4 } \cline { 5 - 6 }
\end{tabular}


Table 4: Summary of clones analyzed and the actin sequences per oyster sample with the corresponding accession number.

\begin{tabular}{|c|c|c|c|c|c|c|}
\hline Location & Ostrea sp. & Samples & Clones & Sequences & Nomenclature & Accession Number \\
\hline Tunisia (TN) & O. stentina & 2 & 2 & 1 & Be_O.stentina_TN & KM073090 \\
\hline Turkey (TR) & O. edulis & 2 & 4 & 1 & Be_O.edulis_TR & KM073091 \\
\hline United Kingdom (UK) & O. edulis & 1 & 3 & 1 & Be_O.edulis_UK & KM073092 \\
\hline $\begin{array}{l}\text { France Atlantic coast } \\
\text { (FR.Atl) }\end{array}$ & O. edulis & 3 & 8 & 1 & Be_O.edulis_FR.Atl & KM073093 \\
\hline Italy (IT) & O. edulis & 1 & 3 & 1 & Be_O.edulis_IT & KM073094 \\
\hline Chile (CL) & O. chilensis & 1 & 1 & 1 & Bsp._O.chilensis_CL & KM073095 \\
\hline New Zealand (NZ) & O. chilensis & 2 & 5 & 2 & $\begin{array}{l}\text { Be_O.chilensis_NZ_clone1 } \\
\text { Be_O.chilensis_NZ_clone2 }\end{array}$ & $\begin{array}{l}\text { KM073096 } \\
\text { KM073097 }\end{array}$ \\
\hline $\begin{array}{l}\text { France Mediterranean } \\
\text { coast (FR.Med) }\end{array}$ & O. edulis & 2 & 6 & 2 & $\begin{array}{l}\text { Be_O.edulis_FR.Med_clone1 } \\
\text { Be_O.edulis_FR.Med_clone2 }\end{array}$ & $\begin{array}{l}\text { KM073098 } \\
\text { KM073099 }\end{array}$ \\
\hline Australia (AU) & O. angasi & 2 & 3 & 3 & $\begin{array}{l}\text { Be_O.angasi_AU_clone1 } \\
\text { Be_O.angasi_AU_clone2 } \\
\text { Be_O.angasi_AU_clone3 }\end{array}$ & $\begin{array}{l}\text { KM073100 } \\
\text { KM073101 } \\
\text { KM073102 }\end{array}$ \\
\hline Spain (SP) & O. edulis & 1 & 5 & 4 & $\begin{array}{l}\text { Be_O.edulis_SP_clone1 } \\
\text { Be_O.edulis_SP_clone2 } \\
\text { Be_O.edulis_SP_clone3 } \\
\text { Be_O.edulis_SP_clone4 }\end{array}$ & $\begin{array}{l}\text { KM073103 } \\
\text { KM073104 } \\
\text { KM073105 } \\
\text { KM073106 }\end{array}$ \\
\hline
\end{tabular}


Table 5: Pairwise distance between $B$. exitiosa actin (BeAct), $B$. ostreae actin gene-1 (BoAct1) and B. ostreae actin gene-2 (BoAct2) and actin sequences obtained in Bonamia sp. infected oysters from different geographical origin (Maximum Composite Likelihood model).

\begin{tabular}{llccc} 
& Geographical origin & BeAct & BoAct1 & BoAct2 \\
\hline Be_O.chilensis_NZ_clone1 & New Zealand & 0.000 & 0.258 & 0.281 \\
Be_O.angasi_AU_clone3 & Australia & 0.000 & 0.258 & 0.281 \\
Be_O.edulis_FR.Atl & France Atlantic Coast & 0.000 & 0.258 & 0.281 \\
Be_O.edulis_FR.Med_clone2 & France Mediterranean Coast & 0.000 & 0.258 & 0.281 \\
Be_O.edulis_UK & United Kingdom & 0.000 & 0.258 & 0.281 \\
Be_O.edulis_IT & Italy & 0.000 & 0.258 & 0.281 \\
Be_O.edulis_TR & Turkey & 0.000 & 0.258 & 0.281 \\
Be_O.stentina_TN & Tunisia & 0.000 & 0.258 & 0.281 \\
Be_O.chilensis_NZ_clone2 & New Zealand & 0.005 & 0.263 & 0.286 \\
Be_O.angasi_AU_clone1 & Australia & 0.005 & 0.263 & 0.286 \\
Be_O.edulis_FR.Med_clone1 & France Mediterranean Coast & 0.005 & 0.258 & 0.286 \\
Be_O.angasi_AU_clone2 & Australia & 0.009 & 0.267 & 0.290 \\
Be_O.edulis_SP_clone3 & Spain & 0.029 & 0.244 & 0.286 \\
Be_O.edulis_SP_clone2 & Spain & 0.034 & 0.244 & 0.281 \\
Bsp._O.chilensis_CL & Chile & 0.034 & 0.249 & 0.290 \\
Be_O.edulis_SP_clone1 & Spain & 0.039 & 0.253 & 0.295 \\
Be_O.edulis_SP_clone4 & Spain & 0.044 & 0.249 & 0.295 \\
\hline
\end{tabular}




\section{Figure 1}

1 ctggacgacatggagaaaatctggcaccacaccttcttcaacgaactcagagtcgcgccc

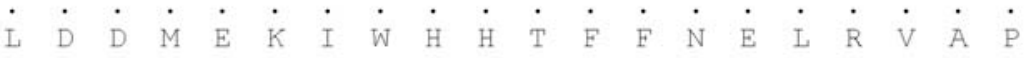

61 gaagaacaccccgttctcctcaccgaagcgccgctcaatcccaaagccaaccgcgagaag

$t$

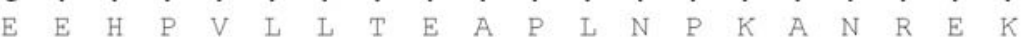

121 atgacgcagatcatgttcgaaacettcaacacgccggccatgtacgtcgccatccaagcc

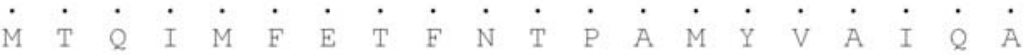

181 gtcctctcctctacgcctccggcagaacgaccggaatcgtcttggactcoggagacggc

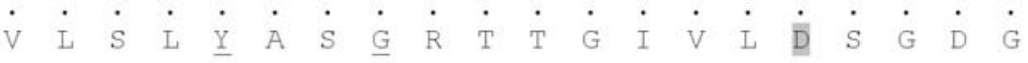

241 gtcagccacaccgtgccgatctacgaaggatacgctctccccacgccatcctcagattg

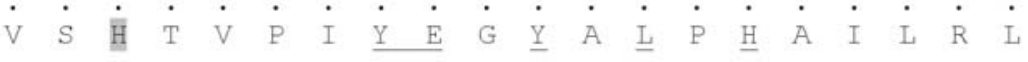

301 gacatcgceggaagagacttgaccgactacttgatcaaaatcctcaccgagcgcggctac

361 agcttcaccaccaccgccgaacgcgaaatcgtccgggacatcaaagaaaacctctgctac

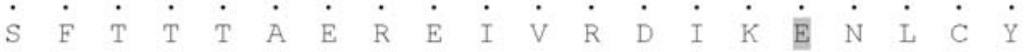

421 tgcgegaccaactttgaaaagagatggcetcogcgaactcoagctcogagatcgagaag

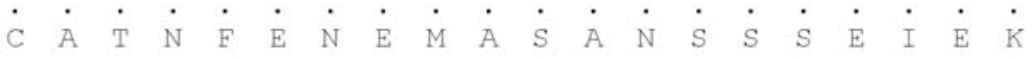

481 acctacgaactcccggatggccagactttgaccatcggaaacgaacgtttcagaattcca

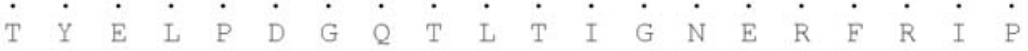

541 gaagttctgttcgatccttctctgatcggcagcgaatcgatgggaattcacagactcgcg

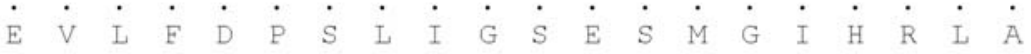

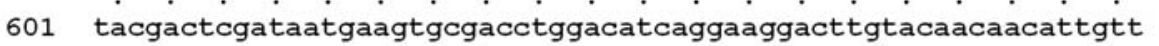

661 ttgtctggtggcagcacgatgtacccgaagatcgagacgcgegtgcagacggagattgcg

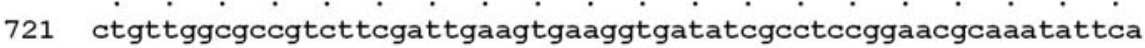

781 gtgtggatcggeggatcgattttgtcttctctgtcgacgttccagcagatgtggataagc

841 aaggacgaatacgatgaatccggtcca 


\section{Figure 2}

Bo Act 1-2

Bo Act 1-14

Bo Act 1-1

Be Act

Bo Act 2-26

Bo Act 2- 45

Bo Act 2-34

Bo Act 1-2

Bo Act 1-1

Bo Act1 1

Be Act

Bo Act $2-26$

Bo Act 2-45

Bo Act 1-2

Bo Act 1-14

Bo Act1 1

Bo Act 2-2

Bo Act 2-2

Bo Act 2-45

1 NWDDMEKIWHHSFFNELRVAPEEHPVLLTEAPLNPKANREKMTQIMFETFNTPAMYVAIQAVLSLYASGRTTGIVLDSGDGVSHTVPIYEGYALPHAILRLDIAGRDLTDYLIKILTERG

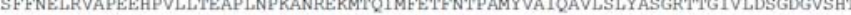
DDMKTHSFENLRVAPEEHPVLLTEAPLNPKANREKMTQIMFETFNTPAMYVAIQAVLSLYASGRTTGIVLDSGDGVSHTVPTYEGYALPHAILRLDIAGRDLTDYLIKILIERG L NWDDMEKIWHHSFFNELRVAPEEHPVLLTEAPLNPKANREKMTQIMFETFNTPAMYVAIQAVLSLYASGRTTGIVLDSGDGVSHTVPIYEGYALPHAILRLDIAGRDLTDYLIKILTERG NWDDMEKIWHHSFFNELRVAPEEHPVLLTEAPLNPKANREKMTQIMFETFNTPAMYVAIQAVLSLYASGRTTGIVLDSGDGVSHTVPIYEGYALPHAILRLDIAGRDLTDYLIKILTERG

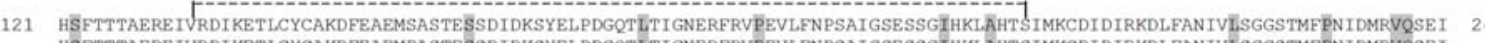

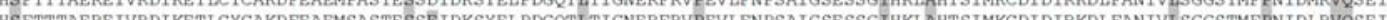

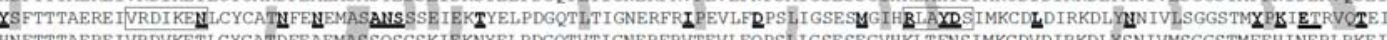
NOFFT

SLIAPSSIEVKVICPPERKYSVWIGGSILSSLSTFQQMWITKRDEYDESO-

SMMAPSSIKINYIAPPERKYR--

$::: * * * * t::: * *, * * * * * *$ 


\section{Figure 3}

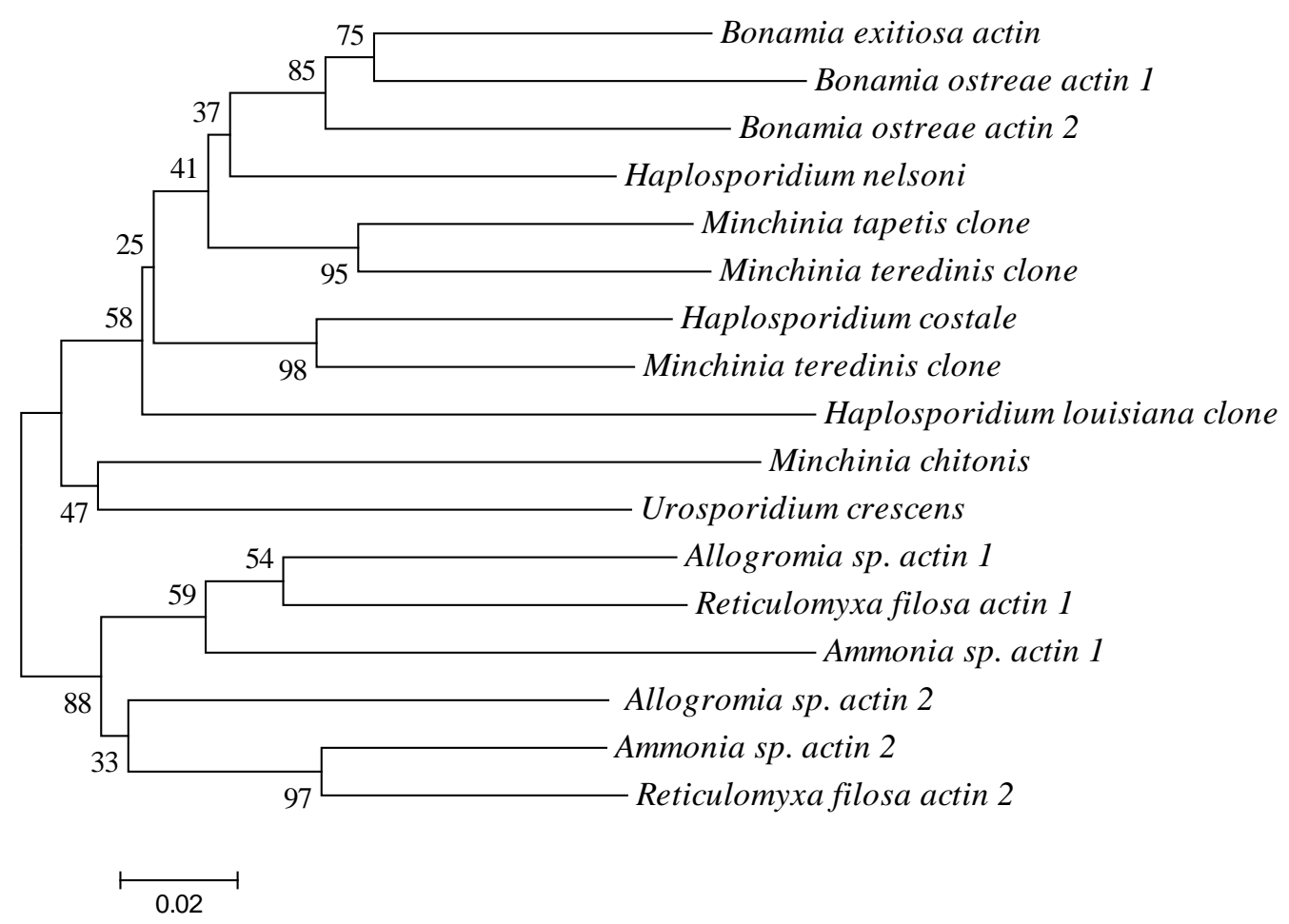




\section{Figure 4}

\section{A}

Consensus

BeAct

Be_O.chilensis_NZ_clonel

$\mathrm{Be}-0$. angasi $\mathrm{AU}^{-} \mathrm{clone} 3$

Be_O.edulis_FR.At]

Be_O.edulis_FR.Med_clone2

Be_o.edulis_UK

$\mathrm{Be}$-o.stentiña TN

Be-o.edulis $\mathrm{T} \overline{\mathrm{R}}$

$\mathrm{Be}$ O.chilensis $\mathrm{NZ}$ clone2

$\mathrm{Be} O$.angasi $\mathrm{AU}^{-} \mathrm{Cl}$ -

$\mathrm{Be}-$. angasi AU Clone?

$\mathrm{Be}-$.edul is FR.Med Clonel

Bsp. . O.chilensis_C $\bar{L}$

Be_o.edulis_SP_clone 1

Be_o.edulis SP clone?

$\mathrm{Be}^{-} \mathrm{O}$. dulis ${ }^{-} \mathrm{SP}^{-} \mathrm{Clone} 4$

Consensus

BeAct

Be_o.chilensis_NZ_clone

$\mathrm{Be} \mathrm{O}$. angasi $\mathrm{AU}$ Clone

Be O.edul is FR.Atl

Be_O.edulis_FR.Med_clone2

Be_o.edulis_UK

Be_o.edulis_IT

Be-O.stentina TN

$\mathrm{Be}^{-} \mathrm{O}$.chilensis NZ clone?

$\mathrm{Be}{ }^{-} \mathrm{O}$.angasi_AU_clone

$\mathrm{Be} 0$. angasi_AU Clone2

Be_O.edulis_FR.Med_clone

Bsp._o.chilensis_CL

Be_o.edulis_SP clone1

Be_o.edulis_SP_clone2

Re_n.e.dul is_SP_clone?

$\mathrm{Be}^{-}$O.edulis $\mathrm{SP}^{-}$clone 4
TCCGGGACATCAAAGAAAACCTCTGCTACTGCGCGACCAACTTTGAAAACGAGATGGCCTCCGCGAACTCCAGCTCCGAGATCGAGAAGACCTACGAACTCCCGGATGGCCAGACTTT GA TCCGGGACATCAAAGAAAACCTCTGCTACTGCGCGACCAACTTTGAAAACGAGATGGCCTCCGCGAACTCCAGCTCCGAGATCGAGAAGACCTACGAACTCCCGGATGGCCAGACTTTGA TCCGGACATCAAAGAAAACCTCTGCTACTGCGCGACCAACTE TCCGGGACATCAAAGAAAACCTCTGCTACTGCGCGACCAACTTTGAAAACGAGATGGCCTCCGCGACTCCAGCTCCGAGATCGAGAGACCTACGAACTCCCGGATGGCCAGACTTTTGA CCGGGACATCAAAGAAAACCTCTGCTACTGCGCGACCAACTTTGAAAACGAGATGGCCTCCGCGACTCCAGCTCCGAGATCGAGAAGACCTACGAACTCCCGGATGGCCAGACTTTTGA TCCGGGACATCAAAGAAAACCTCTGCTACTGCGCGACCAACTTTTAAAACGAGATGGCCTCCGCGAACTCCAGCTCCGAGATCGAGAAGACCTACGAACTCCCGGATGGCCAGACTTTGE TCCGGGACATCAAAGAAAACCTCTGCTACTGCGCGACCAACTTTGAAAACGAGATGGCCTCCGCGAACTCCAGCTCCGAGATCGAGAAGACCTACGAACTCCCGGATGGCCAGACTTTTGA TCCGGGACATCAAAGAAAACCTCTGCTACTGCGCGACCAACTTTGAAAACGAGATGGCCTCCGCGAACTCCAGCTCCGAGATCGAGAAGACCTACGAACTCCCGGATGGCCAGACTTTTGA TCCGGGACATCAAAGAAAACCTCTGCTACTGCGCGACCAACTTTTGAAACGAGATGGCCTCCGCGAACTCCAGCTCCGAGATCGAGAAGACCTACGAACTCCCGGATGGCCAGACTTTTGA TCCGGGACATCAAAGAAAACCTCTGCTACTGCGCGACCAACTTTGAAAACGAGATGGCCTCCGCGAACTCCAGCTCCGAGATCGAGAAGACCTACGAACTCCCGGATGGCCAGACTTTGA TCCGGGACATCAAAGAAAACCTCTGCTACTGCGCGACCAACC̈TTGAAAACGAGATGGCCTCCGCGAACTCCAGCTCCGAGATCGAGAAGACCTACGAACTCCCGGATGGCCAGACTTTIGA TCCGGGACATCAAAGAAAACCTCTGCTACTGCGCGACCAACTTTTGAAAACGAGATGGCCTCCGCGAACTCCAGCCCCCGAGATCGAGAAGACCTACGAACTCCCGGATGGCCAGACTTTGA TCCGGGACATCAAAGAAAACCTCTGCTACTGCGCGACCAACC̈TTTAAGAACGAGATGGCCTCCGCGAACTCCAGCTCCGAGATCGAGAAGACCTACGAACTCCCGGATGGCCAGACTTTGA TCCGGGACATCAAAGAAAACCTCTGCTACTGCGCGACCAACTTTGAAAACGAGATGGCCTCCGCGAGCTCCAGCTCCGAGATCGAGAAGACCTACGAACTCCCGGATGGCCAGACTTTGA --TGGGACATCAAAGAAAACCTCTGCTACTGCGCGACCAACTTT GAAAACGAGATGTCCGC̄̈GCGAACTCCAGCTCCGAGATCGAGAAGACCTACGAACTCCCÄGATGGCCA ÄACTTTGA TCCGGGACATCAAAGAAAACCTCTGCTACTGCGCGACCAACTTTGAAAACGAGATGTCCGCAGCGAACTCCAGCTCCGAGATCGAGAAGACCTACGAACTCCCAGATGGCCAAACTTTGA TCCGGGACATCAAAGAAAACCTCTGCTACTGCGCGACCAACTTTTGAAAACGAGATGTCCGCAGCGAACTCCAGCTCCGAGATCGAGAAGACCTACGAACTCCCAGATGGCCAAACTTTGA TCCGGGACATCAAAGAAAACCTCTGCTACTGCGCGACCAACTTTTGAAAACGAGATGTCCGCAGCGAACTCCAGCTCCGAGATCGAGAAGACCTACGAACTCCCAGATGGCCAAACTTTGA TCCGGGACATCAAAGAAAACCTCTGCTACTGCGCGACCAACTTTTGAAAACGAGATGTCCGTAGCGAACTCCAGCTCCGAGATCGAGAAGACCTACGAACTCCCAGATGGCCAAACTTTGA

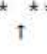

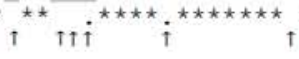
$\uparrow$

CCATCGGAAACGAACGTTTCAGAATTCCAGAAGTTCTGTTCGATCCTTCTCTGATCGGCAGCGAATCGATGGGAATTCACAGACTCGCGTACGACTCGA CCATCGGAAACGAACGTTTCAGAATTCCAGAAGTTCTGTTCGATCCTTCTCTGATCGGCAGCGAATCGATGGGAATTCACAGACTCGCGTACGACTCGA CCATCGGAAACGAACGTTTCAGAATTCCAGAAGTTCTGTTCGATCCTTCTCTGATCGGCAGCGAATCGATGGGAATTCACAGACTCGCGTACGACTCGA CCATCGGAAACGAACGTTTCAGAATTCCAGAAGTTCTGTTCGATCCTTCTCTGATCGGCAGCGAATCGATGGGAATTCACAGACTCGCGTACGACTCGA CCATCGGAAACGAACGTTTCAGAATTCCAGAAGTTCTGTTCGATCCTTCTCTGATCGGCAGCGAATCGATGGGAATTCACAGACTCGCGTACGACTCGA CCATCGGAAACGAACGTTTCAGAATTCCAGAAGTTCTGTTCGATCCTTCTCTGATCGGCAGCGAATCGATGGGAATTCACAGACTCGCGTACGACTCGA CCATCGGAAACGAACGTTTCAGAATTCCAGAAGTTCTGTTCGATCCTTCTCTGATCGGCAGCGAATCGATGGGAATTCACAGACTCGCGTACGACTCGA CCATCGGAAACGAACGTT'TCAGAATTCCAGAAGTTCTGTTCGATCC TTCTCTGATCGGCAGCGAATCGATGGGAATTCACAGACTCGCGTACGACTCGA CCATCGGAAACGAACGTTTCAGAATTCCAGAAGTTCTGTTCGATCCTTCTCTGATCGGCAGCGAATCGATGGGAAT"TCACAGACTCGCGTACGACT'CGA CCATCGGAAACGAACGTTTCAGAATTCCAGAAGTTCTGTTCGATCCTTCTCTGATCGGCAGCGAATCGATGGGAATTCACAGACTCGCGTACGACTCGA CCATCGGAAACGAACGTTTCAGAATTCCAGAAGTTCTGTTCGATCCTTCTCTGATCGGCAGCGAATCGATGGGAATTCACAGACTCGCGTACGACTCGA CCATCGGAAACGAACGTTTCAGAATTCCAGAAGTTCTGTTCGATCCTTCTCTGATCGGCAGCGAATCGATGGGAATTCACAGACTCGCGTACGACTCGA CCATCGGAAACGAACGTTTCAGAATTCCAGAAGTTCTGTTCGATCCTTCTCTGATCGGCAGCGAATCGATGGGAATTCACAGACTCGCGTACGACTCGA CCATCGGAAACGAACGTTCAGAATTCCAGAAGTTTGTTCGATCCTTCTCTGATCGGCAGCGAATCGATGGGAATTCACAGACTCGCGTACGACTCGA CCATCGGAAACGAACGTTTCAGAATTCCAGAAGTTCT GTTCGATCCTTCTCTCATCGGCAGCGAATCGATGGGAATTCACAGACTCGCGTACGACTCGA CCATCGGAAACGAACGTTTCAGAACTCCAGAAGTTCTGTTCGATCCTTCTCTCATCGGCAGCGAATCGATGGGAATTCGCAGACTCGCGTACGACTCGA CCATCGGAAACGAACGTTT CAGAATTCCAGAAGTTCT GTTCGATCCTTCTCTCATCGGCAGCGAATCTATGGGAATTCACAGACTCGCGTACGACTCGA CCATCGGAAACGAACGITCAGAATTCCAGAAGTTCTICGATCCTICTCTCATCGGCAGCGAATCGATGGGAATCACAGACTCGCGTACGACTCGA

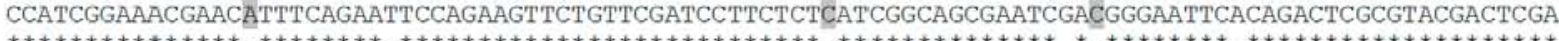

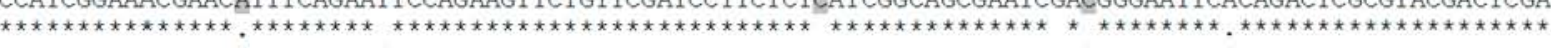




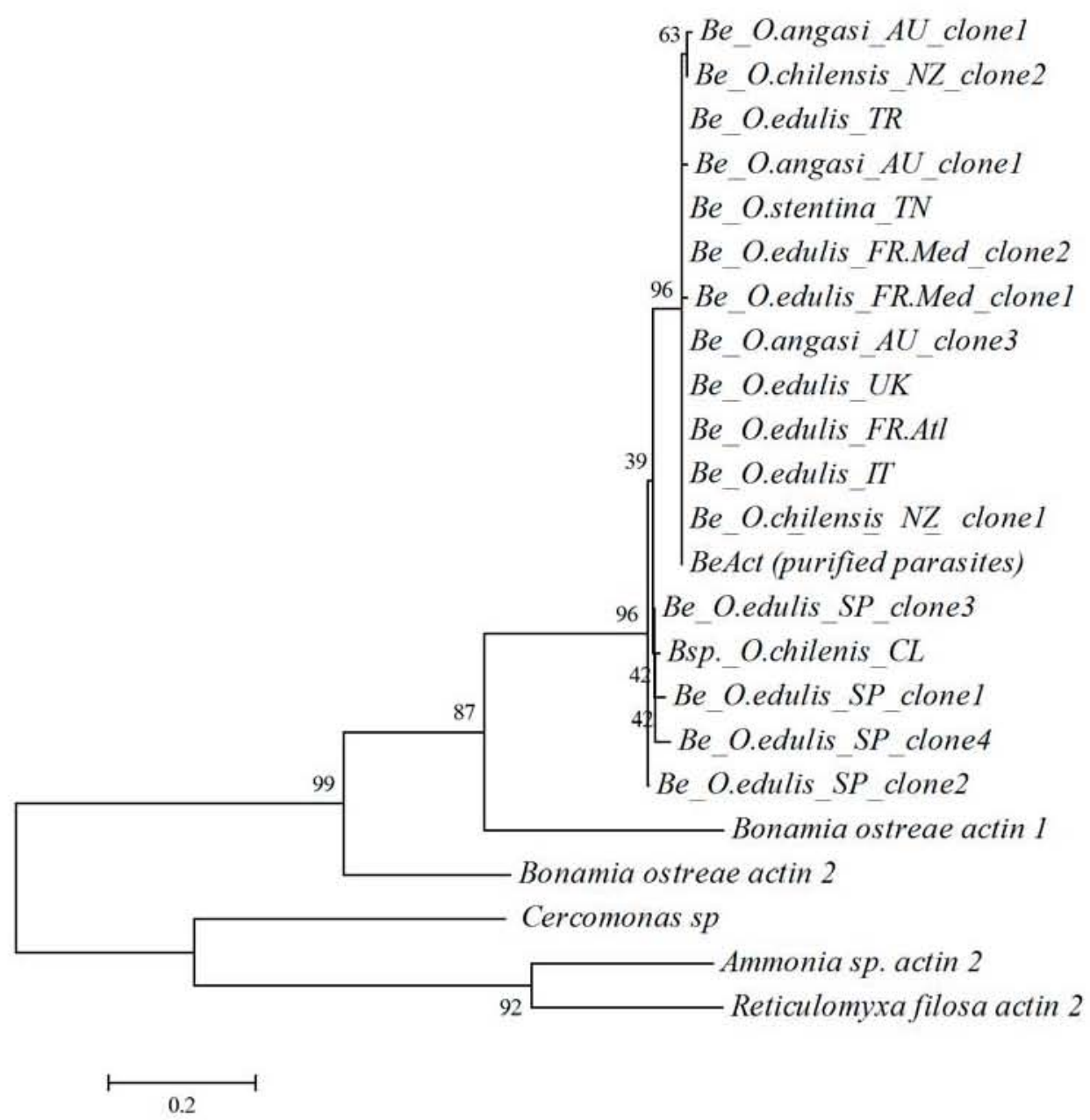

